\title{
COMPLETE MITOCHONDRIAL GENOME SEQUENCE OF A HUNGARIAN RED DEER (CERVUS ELAPHUS HIPPELAPHUS) FROM HIGH-THROUGHPUT SEQUENCING DATA AND ITS PHYLOGENETIC POSITION WITHIN THE FAMILY CERVIDAE
}

\author{
Krisztián Frank, ${ }^{1,2}$ Endre Barta, ${ }^{2}$ Nóra Á. Bana, ${ }^{1}$ JánOs NAgY,${ }^{3}$ \\ PÉTER Horn, ${ }^{1}$ LÁSZló Orosz ${ }^{2,4}$ and VIKTOR STÉGER ${ }^{2 *}$
}

${ }^{1}$ Department of Animal Breeding Technology and Management Faculty of Agricultural and Environmental Sciences, Kaposvár University, Guba Sándor u. 40, H-7400 Kaposvár, Hungary ${ }^{2}$ Agricultural Biotechnology Institute - National Agricultural Research and Innovation Center, Szent-Györgyi Albert u. 4, H-2100 Gödöllö, Hungary

${ }^{3}$ Game Management Landscape Center of Kaposvár University, Malom u. 3, H-7475 Böszénfa, Hungary ${ }^{4}$ Department of Genetics, Faculty of Sciences, Eötvös Loránd University, Pázmány Péter s. 1/c, H-1117 Budapest, Hungary

(Received: August 10, 2015; accepted: November 11, 2015)

Recently, there has been considerable interest in genetic differentiation in the Cervidae family. A common tool used to determine genetic variation in different species, breeds and populations is mitochondrial DNA analysis, which can be used to estimate phylogenetic relationships among animal taxa and for molecular phylogenetic evolution analysis. With the development of sequencing technology, more and more mitochondrial sequences have been made available in public databases, including whole mitochondrial DNA sequences. These data have been used for phylogenetic analysis of animal species, and for studies of evolutionary processes.

We determined the complete mitochondrial genome of a Central European red deer, Cervus elaphus hippelaphus, from Hungary by a next generation sequencing technology. The mitochondrial genome is 16 $354 \mathrm{bp}$ in length and contains 13 protein-coding genes, two rRNA genes, 22 tRNA genes and a control region, all of which are arranged similar as in other vertebrates. We made phylogenetic analyses with the new sequence and 76 available mitochondrial sequences of Cervidae, using Bos taurus mitochondrial sequence as outgroup. We used 'neighbor joining' and 'maximum likelihood' methods on whole mitochondrial genome sequences; the consensus phylogenetic trees supported monophyly of the family Cervidae; it was divided into two subfamilies, Cervinae and Capreolinae, and five tribes, Cervini, Muntiacini, Alceini, Odocoileini, and Capreolini. The evolutionary structure of the family Cervidae can be reconstructed by phylogenetic analysis based on whole mitochondrial genomes; which method could be used broadly in phylogenetic evolutionary analysis of animal taxa.

Keywords: Cervidae - Cervus elaphus hippelaphus - NGS - mitochondrial DNA - phylogenetics

*Corresponding author; e-mail address: steger@abc.hu 


\section{INTRODUCTION}

The family Cervidae, which includes 54 species of deer, constitutes the second most populous family of artiodactyls [7]. These species are distributed widely throughout the world, including the northern hemisphere as well as South America and Southeast Asia, and they have adapted to various climates and environments. As a result of those mentioned above, they vary widely in size, habitat, and behavior, which makes their classification difficult [3, 9, 22]. Red deer (Cervus elaphus L. 1758) is one of the most abundant and best known deer species. It is one of the most desirable and highly prized trophies (on the royal game for trophies) in Europe. Today it is the prime member of the megafauna in Hungary and according to record trophies stands in the center of wide attention, and has an increasing economic, cultural and ecological importance [1, 18, 29, 36, 38]. Being an important game species, the red deer has been extensively managed, introduced, restocked, and selectively hunted throughout its history and distribution area, and is farmed for meat and for antler products throughout the world $[1,18,28,33,36,38]$. Thus, the species has been the target of genetic studies during the past few decades [3, 23, 28-29, 33, 36, 38].

The mitochondrial genome is a small and circular molecule consisting of $15-20 \mathrm{~kb}$ and is conserved in vertebrates [4, 21, 33]. It contains 37 genes, including 13 proteincoding genes, 22 transfer RNA genes, two rRNA genes, and the control region (D-loop). The excellent characteristics of the mitochondrial genome, such as the small size, its abundance in animal tissues, the strict orthology of encoded genes, and its uniparental inheritance make mitochondrial DNA (mtDNA) a reliable and easy-touse marker for population genetics, reconstruction of phylogenetic relationships among vertebrates, and molecular evolution analysis [3-4, 16, 21, 28, 32-33, 37]. In animals, many phylogenetic trees have been reconstructed from the sequence of single genes or elements, for example, Cytb or the D-loop region. The information provided by single genes or genetic elements is poor, however, and such phylogenetic analyses cannot avoid bias $[5,9,35]$.

Currently, mtDNA sequences are released quickly in public databases, and many mitochondrial genomes are available in GenBank, EMBL-Bank, and the DNA Databank of Japan. The high-throughput and low cost of next-generation sequencing (NGS) enables the efficient generation of large amounts of genome sequence data from which mtDNA sequences can be identified, thus, the release of mitochondrial genome data is expected to increase. In family Cervidae, mtDNA of approximately 34 species have been sequenced, and they are available for researchers, making phylogenetic analysis based on the whole mitochondrial genome feasible.

In this study, we determined and analyzed the complete mtDNA sequence of a Central European red deer from Hungary (Cervus elaphus hippelaphus) using NGS technology. We analyzed the phylogenetic relationships and estimated divergence times based on the complete mitochondrial genomes of family Cervidae retrieved from GenBank. The complete sequence adds to our knowledge of the genetics, the evolution and classification of cervids. 


\section{MATERIALS AND METHODS}

\section{DNA sequencing and assembly}

Total genomic DNA was extracted from blood samples of a deer stag from Game Management Landscape Center of Kaposvár University (Bőszénfa, Hungary) using Duplica Prep Automated DNA/RNA Extraction System (EuroClone S.p.A., Italy). The blood was collected from a living animal performed by a trained veterinarian according to standard veterinary medical practice with a permission from the Hungarian Veterinary Chamber. Isolated DNA samples were sequenced on Illumina HiSeq 2000 platform according to the manufacturer's instructions. The mitochondrial genome sequence was assembled de novo from $2 \times 100$ bp paired-end reads using the MITObim (mitochondrial baiting and iterative mapping) pipeline [6]. In the first step, mirabait program from the MIRA version 4.0.2 package was used to select mitochondrial reads; for baiting we used the Cervus elaphus mitochondrion genome sequence (AB245427). In the second step we used the mitobait.pl script, which carried out three iterative steps to build the mitochondrial genome; the final sequence was trimmed at the ends manually. Sequence analysis was carried out using MEGA6 (Molecular Evolutionary Genetics Analysis version 6.0) [31], tRNA genes were identified by tRNAscan-SE [14]. The complete mtDNA sequence has been deposited into the GenBank (Accession No. KT290948).

\section{Phylogenetic and evolution analysis of Cervidae}

Mitochondrial genome sequences of family Cervidae were searched and downloaded from the National Center for Biotechnology Information website. Taxa names and accession numbers of complete mitochondrial genomes of Cervidae are listed in Table 1. The mitochondrial genome of Bos taurus was also downloaded for use as an outgroup. The complete nucleotide sequences of the $\mathrm{H}$ strand of 78 complete mitochondria were aligned using ClustalW2 [10] and manually adjusted in a few instances. The multiple sequence alignments were input into MEGA6 [31], and phylogenetic analyses were performed with two commonly used method of tree reconstruction. Neighbor-joining (NJ) analysis with the bootstrap test, including 1000 replicates, was performed using pairwise deletion for gaps/missing data [30]. Owing to the unavailability of data partitioning and the general time reversible model in MEGA6, however, the non-partitioned dataset and the best available Tamura-Nei model were used for the NJ reconstruction. Maximum likelihood (ML) analysis with the bootstrap test, with 1000 replicates, was performed using complete deletion for gaps/missing data, with the general time reversible model.

Divergence dates were estimated using a Bayesian relaxed molecular clock approach implemented in Phylo-Bayes 3.1 [11] using the ML topology of Fig. 3. Following previous research $[5,7,37]$, we selected three time constraints for fossil calibration: the first was the oldest fossil of Cervidae ( $20 \pm 2$ mya), the second one was 
Table 1

Species and accession numbers of mitochondrial genome sequences used in this study

\begin{tabular}{|c|c|}
\hline Species & Accession number \\
\hline Alces alces & JN632595 \\
\hline Alces alces cameloides & KP405229 \\
\hline Axis axis & JN632599 \\
\hline Axis porcinus & JN632600 \\
\hline Blastocerus dichotomus & JN632603 \\
\hline Capreolus capreolus 1 & JN632610 \\
\hline Capreolus capreolus 2 & KJ681480 \\
\hline Capreolus capreolus 3 & KJ681481 \\
\hline Capreolus capreolus 4 & KJ681482 \\
\hline Capreolus capreolus 5 & KJ681483 \\
\hline Capreolus capreolus 6 & KJ681484 \\
\hline Capreolus capreolus 7 & KJ681485 \\
\hline Capreolus capreolus 8 & KJ681486 \\
\hline Capreolus capreolus 9 & KJ681487 \\
\hline Capreolus capreolus 10 & KJ681488 \\
\hline Capreolus capreolus 11 & KJ681489 \\
\hline Capreolus capreolus 12 & KJ681490 \\
\hline Capreolus capreolus 13 & KJ681491 \\
\hline Capreolus pygargus 1 & KJ681492 \\
\hline Capreolus pygargus 2 & KJ681493 \\
\hline Capreolus pygargus 3 & KJ681494 \\
\hline Capreolus pygargus 4 & KJ681495 \\
\hline Cervus elaphus & AB245427 \\
\hline Cervus elaphus alxaicus & KP172593 \\
\hline Cervus elaphus hippelaphus & KT290948 \\
\hline Cervus elaphus songaricus 1 & KJ025072 \\
\hline Cervus elaphus songaricus 2 & HQ191429 \\
\hline Cervus elaphus xanthopygus & GU457434 \\
\hline Cervus elaphus yarkandensis & GU457435 \\
\hline Cervus nippon centralis & AB211429 \\
\hline Cervus nippon hortulorum 1 & HQ191428 \\
\hline Cervus nippon hortulorum 2 & GU457433 \\
\hline Cervus nippon kopschi 1 & HQ832482 \\
\hline Cervus nippon kopschi 2 & JN389444 \\
\hline Cervus nippon sichuanicus & JN389443 \\
\hline Cervus nippon taiouanus & EF058308 \\
\hline Cervus nippon yakushimae & AB218689 \\
\hline Cervus nippon yesoensis & AB210267 \\
\hline Dama dama & JN632629 \\
\hline
\end{tabular}


Table 1 (cont.)

\begin{tabular}{|c|c|}
\hline Species & Accession number \\
\hline Dama mesopotamica & JN632630 \\
\hline Elaphodus cephalophus & DQ873526 \\
\hline Elaphurus davidianus 1 & JN632632 \\
\hline Elaphurus davidianus 2 & JN399997 \\
\hline Hippocamelus antisensis & JN632646 \\
\hline Hydropotes inermis 1 & JN632649 \\
\hline Hydropotes inermis 2 & EU315254 \\
\hline Hydropotes inermis argyropus 1 & JX254914 \\
\hline Hydropotes inermis argyropus 2 & KP203884 \\
\hline Mazama americana 1 & JN632656 \\
\hline Mazama americana 2 & JN632657 \\
\hline Mazama gouazoubira & JN632658 \\
\hline Mazama nemorivaga 1 & JN632659 \\
\hline Mazama nemorivaga 2 & JN632660 \\
\hline Mazama rufina & JN632661 \\
\hline Muntiacus crinifrons & AY239042 \\
\hline Muntiacus muntjak & AY225986 \\
\hline Muntiacus reevesi micrurus & EF035447 \\
\hline Muntiacus vuquangensis & FJ705435 \\
\hline Odocoileus hemionus & JN632670 \\
\hline Odocoileus virginianus 1 & JN632671 \\
\hline Odocoileus virginianus 2 & JN632672 \\
\hline Odocoileus virginianus 3 & JN632673 \\
\hline Odocoileus virginianus 4 & HQ332445 \\
\hline Ozotoceros bezoarticus & JN632681 \\
\hline Przewalskium albirostris 1 & JN632690 \\
\hline Przewalskium albirostris 2 & HM049636 \\
\hline Pudu mephistophiles & JN632691 \\
\hline Pudu puda & JN632692 \\
\hline Rangifer tarandus & AB245426 \\
\hline Rangifer tarandus phylarcus & KM506758 \\
\hline Rucervus duvaucelii & JN632696 \\
\hline Rucervus eldi 1 & JN632697 \\
\hline Rucervus eldi 2 & HM138200 \\
\hline Rusa alfredi & JN632698 \\
\hline Rusa timorensis & JN632699 \\
\hline Rusa unicolor swinhoei 1 & EF035448 \\
\hline Rusa unicolor swinhoei 2 & DQ989636 \\
\hline Bos taurus & HM045018 \\
\hline
\end{tabular}


the split between Cervini and Muntiacini ( $9 \pm 1$ mya), and the third one was the oldest fossil of tribe Odocoileini ( $5 \pm 1$ mya). Using such constraints involves the assumption that the age of the oldest fossil attributed to a node is a good approximation of the minimum age of the node. As recommended by [11], the analyses were conducted using the CAT-GTR + Gamma 4 model and a log-normal auto correlated clock relaxation model, calculations were conducted 30,000 cycles sampling posterior rates and dates every 10 cycles. Posterior estimates of divergence dates were then computed from the last 2500 samples accounting for the initial burn-in period.

\section{RESULTS}

\section{Mitochondrial genome sequence of Cervus elaphus hippelaphus}

The complete mtDNA of the Central European red deer is $16354 \mathrm{bp}$ in length, including 22 transfer RNA (tRNA) genes, two ribosomal RNA (rRNA) genes, 13 proteincoding genes and a noncoding region (Table 2 and Fig. 1). The orientation and gene organization are identical to other species of cervids [8, 12-13, 25-27, 33, 35], and to the typical organization in mammals. Most of the mitochondrial genes are encoded on the heavy $(\mathrm{H})$ strand, except the ND6 gene and nine tRNA genes (Fig. 1). The nucleotide composition of the $\mathrm{H}$ strand is $33.3 \%$ of $\mathrm{A}, 24.4 \%$ of $\mathrm{C}, 13.5 \%$ of $\mathrm{G}$ and $28.8 \%$ of $\mathrm{T}$.

The protein-coding genes of the red deer are identical to those of other deer [8, $12-13,25-27,33,35]$. The total length of the 13 protein-coding genes is 11,426 nucleotides. The longest one is the ND5 gene (1821 nucleotides), whereas the shortest is the ATP8 gene (201 nucleotides). Ten out of the 13 protein-encoding genes have an ATG start codon, except the ND2, ND3 and ND5 genes, which have an ATA start codon. Ten of the genes have a complete stop codon, TAA or TAG, while three of them appears to end with an incomplete stop codon (single T or TA).

Twenty-two transfer RNA genes were identified in the mtDNA of red deer. The total length of the 22 tRNA genes is 1523 nucleotides, and ranges from 66 (tRNA ${ }^{\text {Pro }}$ ) to 75 nucleotides (tRNA ${ }^{\text {Leu }}$ ). All tRNA genes have the cloverleaf secondary structure,

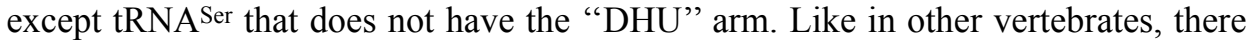
are two ribosomal RNA genes in the red deer mitochondrion. The lengths of the $12 \mathrm{~S}$ rRNA and 16S rRNA are 955 and 1567 nucleotides, respectively, and they are located between tRNA ${ }^{\text {Phe }}$ and tRNA ${ }^{\text {Leu }}$, separated by tRNA ${ }^{\text {Val }}$.

Like in most vertebrates, the light strand replication origin (OL) is between tRNA ${ }^{A s n}$ and tRNA ${ }^{\text {Cys }}$, and consists of 32 nucleotides. The non-coding control region, 920 nucleotides in length, is located between tRNA ${ }^{\text {Pro }}$ and tRNA ${ }^{\text {Phe }}$. The red deer mtDNA control region contains conserved sequence blocks (CSB-F, CSB-E, CSB-D, CSB-C, CSB-B, CSB-1 and CSB-2), and all four termination-associated sequences (TAS-1 to TAS-4) (Fig. 2.). These sequences are highly similar to other species of Cervidae $[2,12-13,25-27,33]$. The conserved sequence blocks, and the termination- 


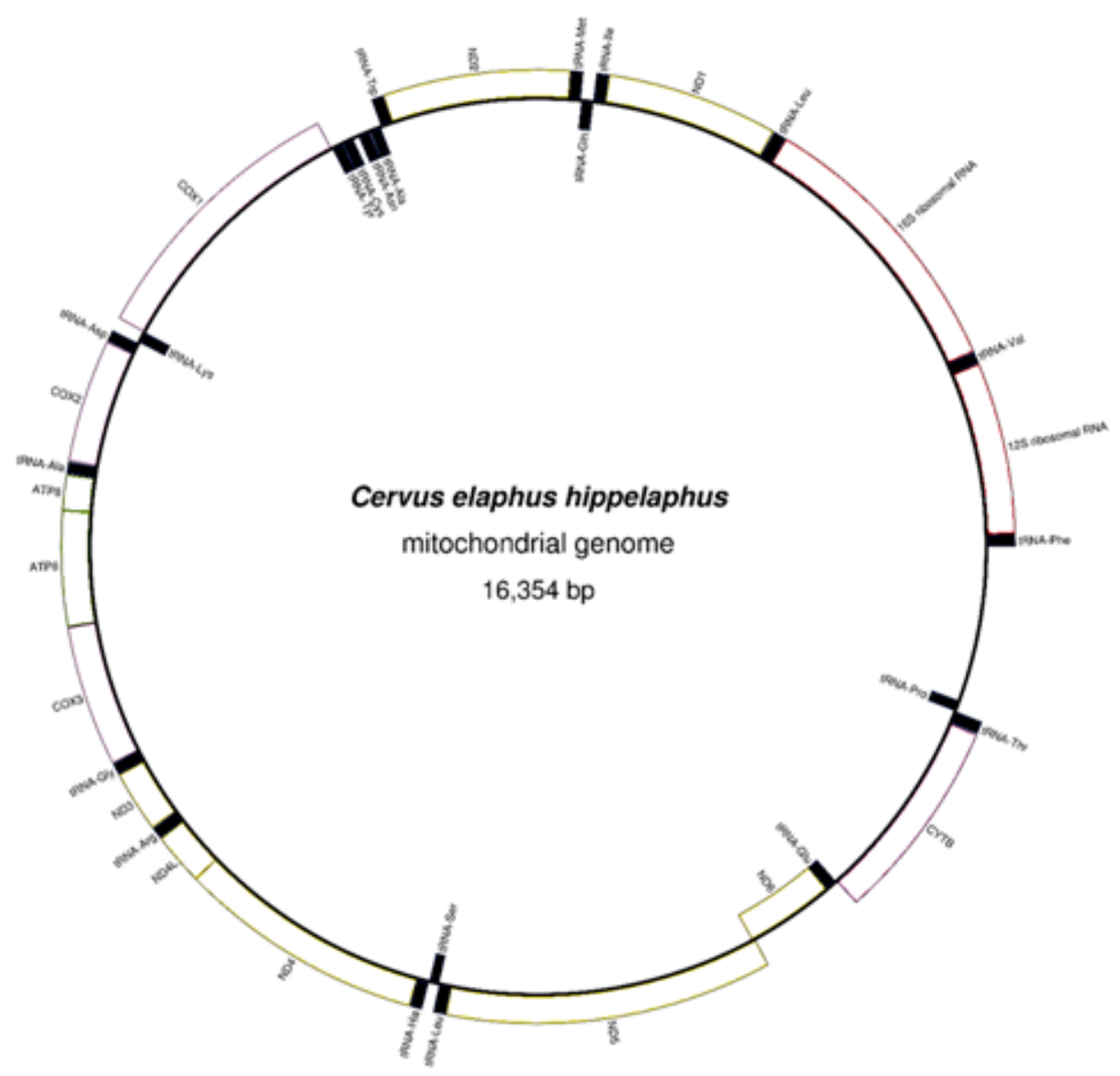

Fig. 1. The map of the Hungarian red deer mitochondrial genome

associated sequences can be used for fine-scale population studies, since they are amongst the most rapidly evolving segments in the animal mtDNA [19, 24, 28].

\section{Mitogenomic phylogeny of the family Cervidae}

The NJ and ML phylogenetic trees, which are based on mitochondrial genome sequences, have similar topology, as shown in Figure 3. All supra-generic taxa described in previous studies [7, 34-35,37] are highly supported, i.e. the subfamily Cervinae with two tribes Cervini and Muntiacini, and the subfamily Capreolinae with three tribes Alceini, Odocoileini and Capreolini. The monophyly of Cervidae was well supported, with a bootstrap value of $100 \%$ in NJ and ML. The intertribal rela- 
Table 2

Genes of the red deer's mitochondrial genome

\begin{tabular}{|c|c|c|c|c|c|c|c|}
\hline Name & Site & Length & $\begin{array}{c}\text { Intergenic } \\
\text { nucleotide }^{\mathrm{a}}\end{array}$ & Strand & Start codon & Stop codon & Anti-codon \\
\hline tRNA ${ }^{\text {Phe }}$ & $1-69$ & 69 & & $\mathrm{H}$ & & & GAA \\
\hline 12S rRNA & $70-1024$ & 955 & 0 & $\mathrm{H}$ & & & \\
\hline tRNA & $1025-1091$ & 67 & 0 & $\mathrm{H}$ & & & TAC \\
\hline 16S rRNA & $1092-2658$ & 1567 & 0 & $\mathrm{H}$ & & & \\
\hline tRNA ${ }^{\text {Leu }}$ & $2664-2738$ & 75 & 5 & $\mathrm{H}$ & & & TAA \\
\hline ND1 & $2741-3697$ & 957 & 2 & $\mathrm{H}$ & ATG & TAA & \\
\hline tRNA & $3697-3765$ & 69 & -1 & $\mathrm{H}$ & & & GAT \\
\hline tRNA ${ }^{G l n}$ & $3763-3834$ & 72 & -3 & $\mathrm{~L}$ & & & TTG \\
\hline tRNAMet & $3837-3905$ & 69 & 2 & $\mathrm{H}$ & & & CAT \\
\hline ND2 & $3906-4949$ & 1044 & 0 & $\mathrm{H}$ & ATA & TAG & \\
\hline tRNA ${ }^{\text {Trp }}$ & $4948-5015$ & 68 & -2 & $\mathrm{H}$ & & & TCA \\
\hline tRNA ${ }^{\text {Ala }}$ & $5018-5086$ & 69 & 2 & $\mathrm{~L}$ & & & TGC \\
\hline tRNA Asn & $5088-5160$ & 73 & 1 & $\mathrm{~L}$ & & & GTT \\
\hline tRNACys & $5193-5260$ & 68 & 32 & $\mathrm{~L}$ & & & GCA \\
\hline $\mathrm{tRNA}^{\mathrm{Tyr}}$ & $5261-5329$ & 69 & 0 & $\mathrm{~L}$ & & & GTA \\
\hline COX1 & $5331-6875$ & 1545 & 1 & $\mathrm{H}$ & ATG & TAA & \\
\hline tRNA Lys & $6873-6941$ & 69 & -3 & $\mathrm{~L}$ & & & CTT \\
\hline tRNA ${ }^{\text {Asp }}$ & $6949-7016$ & 68 & 7 & $\mathrm{H}$ & & & GTC \\
\hline $\mathrm{COX} 2$ & 7018-7701 & 684 & 1 & $\mathrm{H}$ & ATG & TAA & \\
\hline tRNA ${ }^{\text {Ala }}$ & $7705-7772$ & 68 & 3 & $\mathrm{H}$ & & & AGC \\
\hline ATP8 & 7774-7974 & 201 & 1 & $\mathrm{H}$ & ATG & TAA & \\
\hline ATP6 & $7935-8615$ & 681 & -40 & $\mathrm{H}$ & ATG & TAA & \\
\hline $\mathrm{COX} 3$ & 8615-9414 & 800 & -1 & $\mathrm{H}$ & ATG & TA & \\
\hline tRNAGly & 9399-9467 & 69 & -16 & $\mathrm{H}$ & & & TCC \\
\hline ND3 & $9468-9814$ & 347 & 0 & $\mathrm{H}$ & ATA & TA & \\
\hline tRNAArg & 9815-9883 & 69 & 0 & $\mathrm{H}$ & & & TCG \\
\hline ND4L & $9884-10,180$ & 297 & 0 & $\mathrm{H}$ & ATG & TAA & \\
\hline ND4 & $10,174-11,551$ & 1378 & -7 & $\mathrm{H}$ & ATG & $\mathrm{T}$ & \\
\hline tRNA $^{\text {His }}$ & $11,552-11,620$ & 69 & 0 & $\mathrm{H}$ & & & GTG \\
\hline tRNA ${ }^{\text {Ser }}$ & $11,621-11,680$ & 60 & 0 & $\mathrm{~L}$ & & & \\
\hline tRNA ${ }^{\text {Leu }}$ & $11,682-11,751$ & 70 & 1 & $\mathrm{H}$ & & & TAG \\
\hline ND5 & $11,752-13,572$ & 1821 & 0 & $\mathrm{H}$ & ATA & TAA & \\
\hline ND6 & $13,556-14,083$ & 528 & -17 & $\mathrm{~L}$ & ATG & TAA & \\
\hline tRNA Glu & $14,084-14,152$ & 69 & 0 & $\mathrm{~L}$ & & & TTC \\
\hline CYTB & $14,157-15,299$ & 1143 & 4 & $\mathrm{H}$ & ATG & TAA & \\
\hline tRNA ${ }^{\text {Thr }}$ & $15,300-15,369$ & 70 & 0 & $\mathrm{H}$ & & & TGT \\
\hline tRNA ${ }^{\text {Pro }}$ & $15,369-15,434$ & 66 & -1 & $\mathrm{~L}$ & & & TGG \\
\hline
\end{tabular}

${ }^{a}$ Negative numbers indicate that adjacent genes overlap. 


\begin{tabular}{|c|c|c|c|c|c|c|}
\hline 1 & ATGCTTATTA & ATATAGTTCC & ATAAAAATCA & AGAACTTTAT & CAGTATTAAA & TTTCCAAAAA \\
\hline 61 & GTTTTAATAT & TTCAATACAG & СТTТССАСТС & AACATCCATT & TTACATTTTT & TACATCCACT \\
\hline 121 & AACCACACAA & CAAAATATGT & AATGTAAATC & TTATGCGCTT & 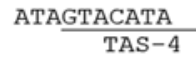 & GAATTAATGT \\
\hline 181 & ACTAGGACAT & ACTATGTATA & 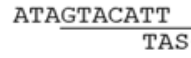 & $\frac{\text { ATATTATATG }}{-3}$ st & $\begin{array}{l}\text { CCCCATGCTT } \\
\text { top }\end{array}$ & ATAAGCATGT \\
\hline 241 & АСТTTСТАTT & ATTTATAGTA & $\frac{\text { CATAGTACAT }}{\text { TAS-2 }}$ & GATGTTGTTC & ATCGTACATA & $\frac{\text { GTGCATTAAG }}{\text { TAS-1 }}$ \\
\hline 301 & TCAAATCAAT & TCTTGTCAAC & ATGCATATCC & CTGCCCCTAG & ATCACGAGCT & TGATCACCAT \\
\hline 61 & $\frac{\text { GCCGCGTGAA }}{\text { CSB-F }}$ & ACCAGCAACC & CGCTGGGCAG & GGATCCCTCT & $\frac{\text { TCTCGCTCCG }}{\text { CSB-E }}$ & $\frac{\text { GGCCCATAAA }}{2}$ \\
\hline 21 & TTGTGGGGGT & AGCTATTTAA & TGAACTTTAT & CAGACATCTG & $\frac{\text { GTTCTTTTTT }}{\text { CSB-D }}$ & CAGGGCCATC \\
\hline 81 & TCACTAAAAA & TCGCCCACTC & $\begin{array}{r}\text { CTTGTAGTAT } \\
\text { CSB }\end{array}$ & $\begin{array}{l}\text { TAGACATCTC } \\
-\mathrm{C}\end{array}$ & GATGGACTAA & TGGCTAATCA \\
\hline 541 & GCCCATGCTC & ACACATAACT & GTGGTGTCAT & $\frac{\text { ACATTTGGTA }}{\text { CSB-B }}$ & TTTTTAATTT & TTGGGGGGAT \\
\hline 01 & GCTTGGACTC & AGCAATGACC & GTCTGGCGGT & CCCGTCCCGG & AGCATGAATT & GTAGCTGGAC \\
\hline 661 & TTAACTGCAT & CTTGAGCATC & $\frac{\text { CCCATAATGG }}{\text { in }}$ & TAGGCATGGG & CATGGCAGTC & $\frac{\mathrm{AATGGTCACA}}{\mathrm{CSB}-1}$ \\
\hline 721 & GGACATAGTC & ATTATTTCAC & GACCCAACTT & TACTATCTAT & $\frac{\text { TTTCCCCCCC }}{\operatorname{CSB}-2}$ & TCCCCAATTT \\
\hline 81 & ТTССССССТА & TATAGTTATC & ACСATTTTTA & АСАСАСТTTТ & СССTAGATAT & TATTTTAAAT \\
\hline 41 & TTATCACATT & TCCAATACTC & AAATTAGCAC & TCCAGGGGGT & GGTAAGTATA & TAAACGCCAA \\
\hline 01 & TTTTTСССТА & TTATATATA & & & & \\
\hline
\end{tabular}

Fig. 2. Sequences and the conserved elements of the control region of the red deer. Primary sequence features (TAS-1, TAS-2, TAS-3, TAS-4, CSB-B, CSB-C, CSB-D, CSB-E, CSB-F, origin of H replication, CSB-1, CSB-2) are underlined and stop (putative point of arrest of the D-loop synthesis) is marked in italics

tionships within Cervinae are robust, but in Capreolinae most intertribal relationships are not robust, suggesting rapid diversifications. The phylogenetic tree showed not only the phylogeny of the whole family but also the monophyly of tribes, such as Muntiacini. The phylogenetic tree suggested classification information within species, for example, the division of Cervus elaphus into two clades: a western clade with C. e. hippelaphus and C. e. yarkandensis, and an eastern clade with C. e. xanthopygus, C. e. alxaicus and C. e. songaricus, which were Asian ecotypes [2, 7, 15, $20,37]$.

\section{Estimation of divergence times in family Cervidae}

Estimated divergence times of family Cervidae are shown in Figure 4. According to the phylogenetic tree, the origin of family Cervidae was estimated to be a mean value of 10.69 mya, indicating that the true divergence times of family Cervidae were later than the fossil evidence suggested. The subfamilies Capreolinae and Cervinae became divided at 9.77 and 8.92 mya, respectively, whereas the five tribes, Cervini, Muntiacini, Alceini, Odocoileini, and Capreolini, were divided at different times. The 


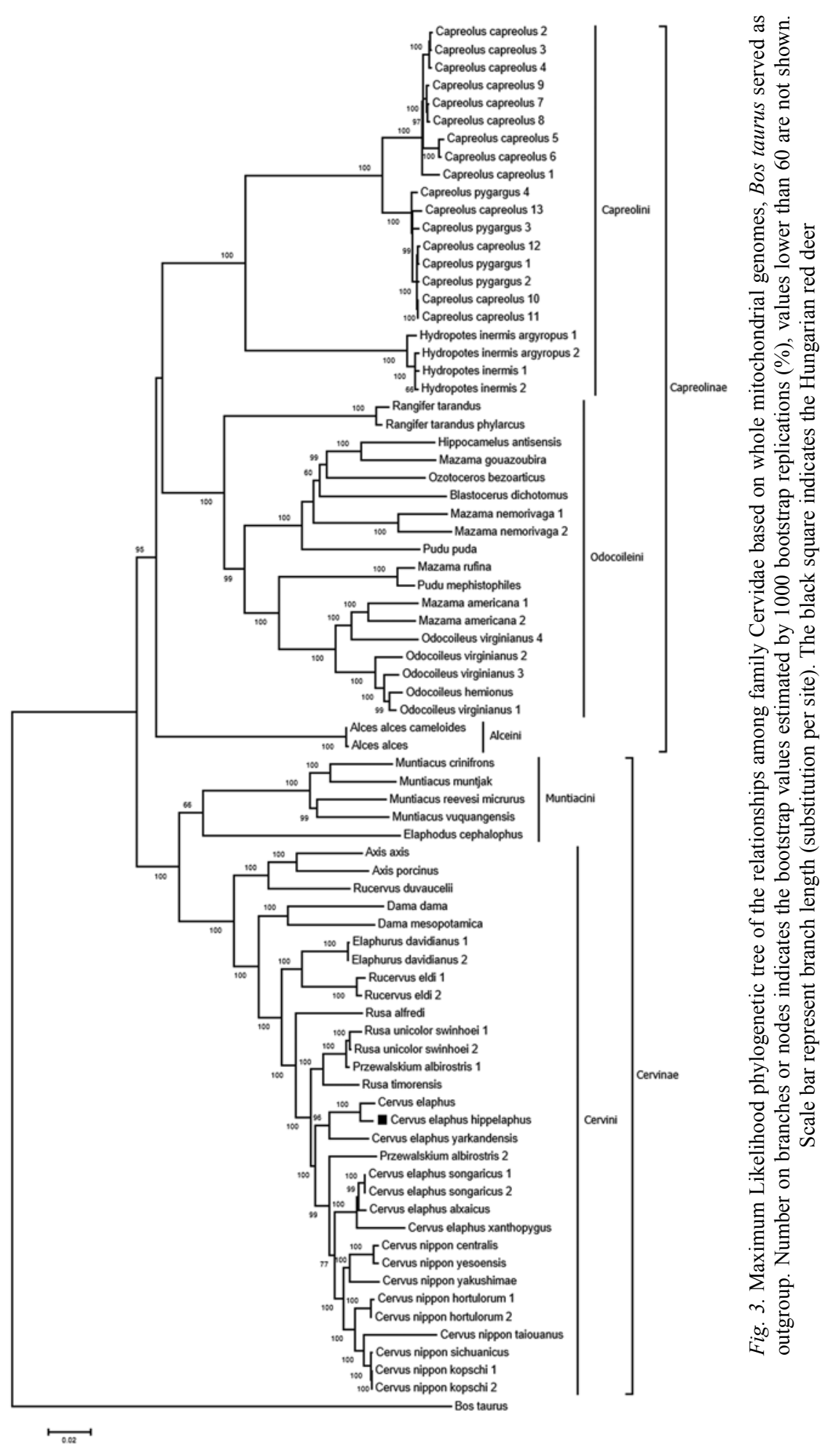




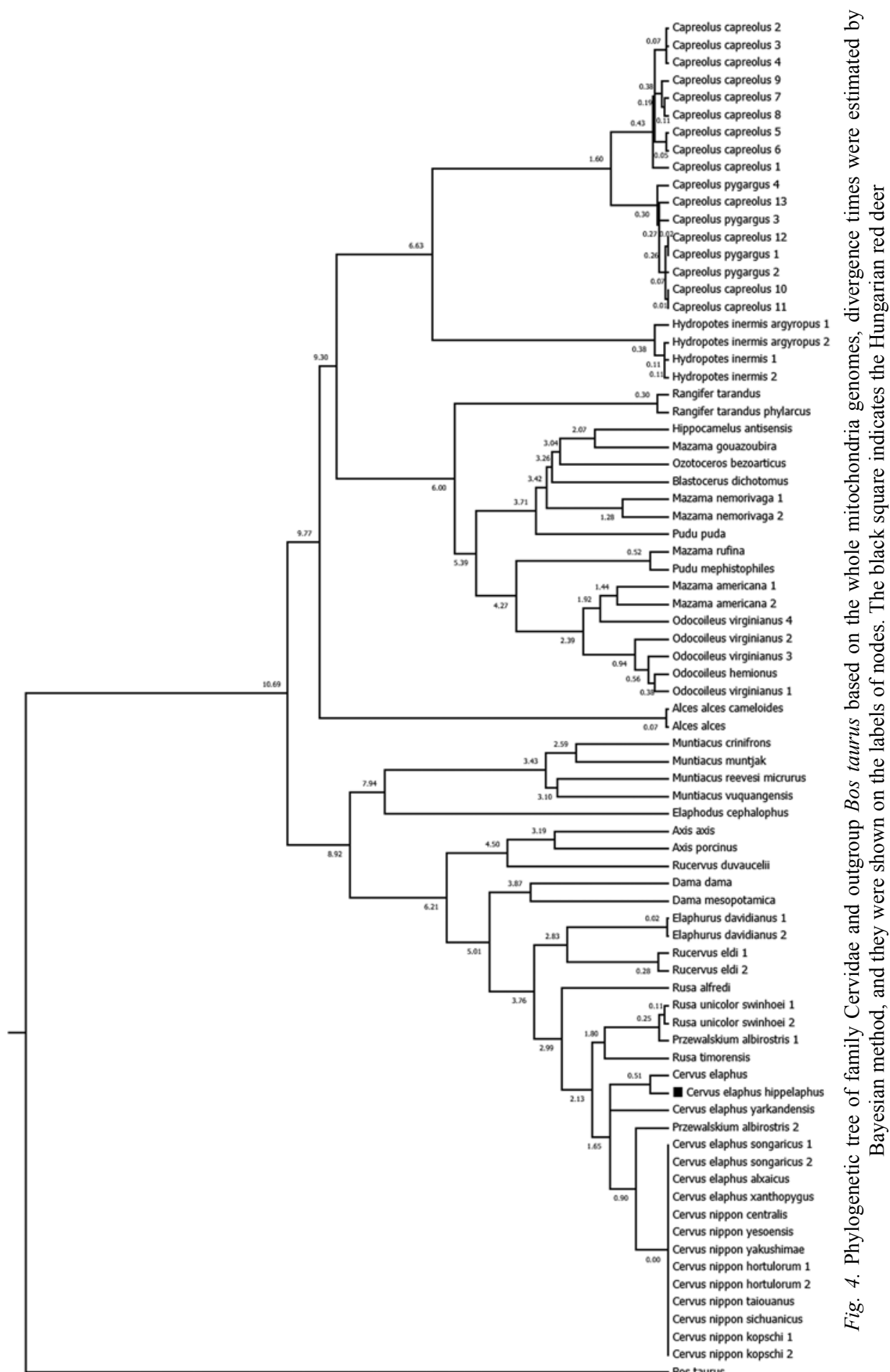

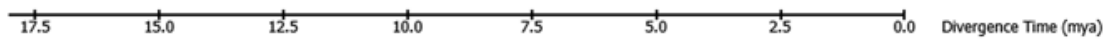


divergence times of some species of Cervidae were very small; e.g. the divergence time between Cervus elaphus songaricus, Cervus elaphus alxaicus, Cervus elaphus xanthopygus, and Cervus nippon subspecies was lower than 0.01 mya, which suggested that they may not belong to two separate species but may belong to the varieties of C. nippon.

\section{DISCUSSION}

During the last two decades, extensive efforts have been made to investigate phylogenetic relationships of Cervidae, and also in Cetartiodactyla [e.g. 3, 5, 7, 9, 17, 20, $22,32,35]$. However, relationships within this group remain unclear. It is possible that different molecular markers have a different evolutionary rate; even if the same markers, the substitution rate varies among taxa. Thus, a single gene or a short DNA sequence applying to phylogeny reconstruction is very likely to produce an incorrect tree topology for a systematic bias and/or long-branch attraction. The complete mitochondrial genome provides a higher level of support for molecular systematics than those based on individual or partial mitochondrial genes $[5,9,21]$. In the present study, we determined the complete mitochondrial genome of a Central European red deer, Cervus elaphus hippelaphus, from NGS data. The protein-coding genes of the red deer are identical to those of other deer species [8, 12-13, 21, 25-27, 33, 35], and have a methionine start codon, ATG or ATA, and mainly also complete stop codons, TAA or TAG. It is common for termination codons to be truncated, to T or TA, in metazoan mitochondrial genomes, such codons are presumably completed as TAA by post-transcriptional polyadenylation [21,33]. The size and orientation of tRNA and rRNA genes are similar to those of other cervids [8, 12-13, 21, 25-27, 33, 35]. The lack of the "DHU" arm in tRNA ${ }^{\text {Ser }}$ has been reported in other species of Cervidae [8, $21,25-27,35]$. The non-coding control region contains conserved sequence blocks, and termination-associated sequences; and can be used for fine-scale population studies, since it is amongst the most rapidly evolving segments in the animal mtDNA [17, 19, 24, 28]. The high-throughput approach for sequencing was useful for obtaining the whole mitochondrial genome of red deer, so this method could be used broadly among animal taxa.

Based on our phylogenetic results using whole mitochondrial genomes, family Cervidae is divided into two subfamilies, Cervinae and Capreolinae, which are also called subfamilies Plesiometacarpalia and Telemetacarpalia $[5,7,22,34,37]$. The two subfamilies contain five tribes, and four of these, Cervini, Muntiacini, Odocoileinae, and Capreolini, are well determined by the phylogenetic trees of family Cervidae. Hungarian red deer joined to the semi-domesticated red deer of New Zealand with a bootstrap value of $100 \%$, and clustered to tarim red deer (C. e. yarkandensis) forming a western clade of red deer. Other Cervus elaphus subspecies, which were Asian ecotypes, formed a second, eastern clade; which is consistent with previous reports $[2,7,12,15,20,37]$. 
The relationships among sika deer inferred from our phylogenetic and evolutionary analyses were inconsistent with subspecies designation, but similar to previous mitochondrial phylogenies $[12,15,35]$. The divergence times (less than 0.01 mya) suggest that Cervus elaphus songaricus, Cervus elaphus alxaicus, Cervus elaphus xanthopygus are more closely related to Cervus nippon than to other Cervus elaphus subspecies. The close relationship of these two groups, as described previously, could be the result of the evolution of the genus Cervus in Asia [5, 7, 9, 15, 22, 35, 36], or maybe it could be attributed to anthropogenic influences as seen in European deer $[18,20,28-29,33,36]$.

The mtDNA distances between several species studied here are smaller than those generally obtained between subspecies $(<2 \%)$, which raises the possibility of species misidentification or imperfect taxonomy (species synonymy). In some cases, the sequences described may have been misidentified. For example in the case of Capreolus species, from which some are described as belonging to Capreolus pygargus [17], but deposited in GenBank as Capreolus capreolus. A second example of possible species assignation error concerns Mazama rufina and Pudu mephistophiles, which share very similar mtDNA genomes (98.6\%). Sequences were obtained from pieces of skin collected in Colombia, where the same name can be used to designate both species, and in addition, both species live in the same habitat, and exhibit the same color pattern [7]. The placement of two isolates of Przewalskium albirostris also suggest species misidentification as they lay on different branches. The placement as the sister species to a $C$. nippon and C. elaphus clade seems the appropriate one as suggested by [22]. The other isolate may be attributed to a misidentified specimen of Rusa spp.

The determined divergence times of the family Cervidae are somewhat higher, than dates estimated from previous molecular phylogenetic analysis [5, 22, 37], which suggested that family Cervidae was present at 7.7-9.6 mya. These time estimates, and also our estimate indicate that the true divergence times within family Cervidae were later than the fossil evidence suggested. The evolution of Cervidae is complex, and relationships within this group are unclear, due to possible species misidentification and imperfect taxonomy.

\section{ACKNOWLEDGEMENTS}

This study was financed by the Ministry of Agriculture, grant number NAIK-MBK/M71411. N. Á. Bana, K. Frank and J. Nagy were supported by the Doctoral School of Animal Science of the Kaposvár University.

\section{REFERENCES}

1. Bán, I. (1998) The Hungarian Wonder Deer. EP Systema, Debrecen.

2. Douzery, E., Randi, E. (1997) The mitochondrial control region of Cervidae: Evolutionary patterns and phylogenetic content. Mol. Biol. Evol. 14, 1154-1166. 
3. Feulner, P. G. D., Bielfeldt, W., Zachos, F. E., Bradvarovic, J., Eckert, I., Hartl, G. B. (2004) Mitochondrial DNA and microsatellite analyses of the genetic status of the presumed subspecies Cervus elaphus montanus (Carpathian red deer). Heredity 93, 299-306.

4. Flegontov, P., Gray, M. W., Burger, G., Lukes, J. (2011) Gene fragmentation: a key to mitochondrial genome evolution in Euglenozoa? Curr. Genet. 57, 225-232.

5. Gilbert, C., Ropiquet, A., Hassanin, A. (2006) Mitochondrial and nuclear phylogenies of Cervidae (Mammalia, Ruminantia). Systematics, morphology, and biogeography. Mol. Phylogenet. Evol. 40, $101-117$.

6. Hahn, C., Bachmann, L., Chevreux, B. (2013) Reconstructing mitochondrial genomes directly from genomic next-generation sequencing reads - a baiting and iterative mapping approach. Nucl. Acids Res. 41, e129.

7. Hassanin, A., Delsuc, F., Ropiquet, A., Hammer, C., Jansen van Vuuren, B., Matthee, C., Ruiz-Garcia, M., Catzeflis, F., Areskoug, V., Nguyen, T. T., Couloux, A. (2012) Pattern and timing of diversification of Cetartiodactyla (Mammalia, Laurasiatheria), as revealed by a comprehensive analysis of mitochondrial genomes. C. R. Biol. 335, 32-50.

8. Ju, Y., Liu, H., Rong, M., Yang, Y., Wei, H., Shao, Y., Chen, X., Xing, X. (2016) Complete mitochondrial genome sequence of Aoluguya reindeer (Rangifer tarandus). Mitochondrial DNA 27, 22612262.

9. Kuwayama, R., Ozawa, T. (2000) Phylogenetic relationships among European red deer, wapiti, and sika deer inferred from mitochondrial DNA sequences. Mol. Phylogenet. Evol. 15, 115-123.

10. Larkin, M. A., Blackshields, G., Brown, N. P., Chenna, R., McGettigan, P. A., McWilliam, H., Valentin, F., Wallace, I. M., Wilm, A., Lopez, R., Thompson, J. D., Gibson, T. J., Higgins, D. G. (2007) Clustal W and Clustal X version 2.0. Bioinformatics 23, 2947-2948.

11. Lartillot, N., Lepage, T., Blanquart, S. (2009) PhyloBayes 3: a Bayesian software package for phylogenetic reconstruction and molecular dating. Bioinformatics 25, 2286-2288.

12. Li, Y., Ba, H., Yang, F. (2016) Complete mitochondrial genome of Cervus elaphus songaricus (Cetartiodactyla: Cervinae) and a phylogenetic analysis with related species. Mitochondrial DNA $620-621$.

13. Liu, Z., Wang, J., Sun, Y., Hou, Z., Teng, L. (2015) Complete mitochondrial genome of a wild Alashan Red Deer (Cervus elaphus alxaicus). Mitochondrial DNA Early Online.

14. Lowe, T. M., Eddy, S. R. (1997) tRNAscan-SE: a program for improved detection of transfer RNA genes in genomic sequence. Nucl. Acids Res. 25, 955-964.

15. Mahmut, H., Masuda, R., Onuma, M., Takahashi, M., Nagata, J., Suzuki, M., Ohtaishi, N. (2002) Molecular phylogeography of the red deer (Cervus elaphus) populations in Xinjiang of China: Comparison with other Asian, European, and North American populations. Zool. Sci. 19, 485-495.

16. Marincs, F., Molnár, J., Tóth, G., Stéger, V., Barta, E. (2013) Introgression and isolation contributed to the development of Hungarian Mangalica pigs from a particular European ancient bloodline. Genet. Sel. Evol. 45, 22.

17. Matosiuk, M., Sheremetyeva, I. N., Sheremetyev, I. S., Saveljev, A. P., Borkowska, A. (2014) Evolutionary neutrality of mtDNA introgression: evidence from complete mitogenome analysis in roe deer. J. Evol. Biol. 27, 2483-2494.

18. Milner, J. M., Bonenfant, C., Mysterud, A., Gaillard, J. M., Csányi, S., Stenseth, N. C. (2006) Temporal and spatial development of red deer harvesting in Europe: biological and cultural factors. J. Appl. Ecol. 43, 721-734.

19. Molnár, J., Tóth, G., Stéger, V., Zsolnai, A., Jánosi, A., Mohr, A., Szántó-Egész, R., Tóth, P., Micsinai, A., Rátky, J., Marincs, F. (2013) Mitochondrial D-loop analysis reveals low diversity in Mangalica pigs and their relationship to historical specimens. J. Anim. Breed. Genet. 130, 312-320.

20. Olivieri, C., Marota, I., Rizzi, E., Ermini, L., Fusco, L., Pietrelli, A., De Bellis, G., Rollo, F., Luciani, S. (2014) Positioning the red deer (Cervus elaphus) hunted by the Tyrolean Iceman into a mitochondrial DNA phylogeny. PLOS ONE 9, e100136. 
21. Pang, H., Liu, W., Chen, Y., Fang, L., Zhang, X., Cao, X. (2008) Identification of complete mitochondrial genome of the tufted deer. Mitochondrial DNA 19, 411-417.

22. Pitra, C., Fickel, J., Meijaard, E., Groves, P. C. (2004) Evolution and phylogeny of old world deer. Mol. Phylogenet. Evol. 33, 880-895.

23. Radko, A., Zalewski, D., Rubiś, D., Szumec, A. (2014) Genetic differentiation among 6 populations of red deer (Cervus elaphus L.) in Poland based on microsatellite DNA polymorphism. Acta Biol. Hung. 65, 414-427.

24. Sbisà, E., Tanzariello, F., Reyes, A., Pesole, G., Saccone, C. (1997) Mammalian mitochondrial D-loop region structural analysis: identification of new conserved sequences and their functional and evolutionary implications. Gene 205, 125-140.

25. Shao, Y., Su, W., Liu, H., Zha, D., Zhang, R., Xing, X. (2016) Complete mitochondrial genome sequence of northeastern red deer (Cervus elaphus xanthopygus). Mitochondrial DNA Early Online.

26. Shao, Y., Xing, X., Zha, D., Yang, F. (2016) Complete mitochondrial genome sequence of tarim red deer (Cervus elaphus yarkandensis). Mitochondrial DNA 547-548.

27. Shao, Y., Zha, D., Xing, X., Su, W., Liu, H., Zhang, R. (2016) Complete mitochondrial genome sequence of northeastern sika deer (Cervus nippon hortulorum). Mitochondrial DNA 469-470.

28. Skog, A., Zachos, F. E., Rueness, E. K., Feulner, P. G. D., Mysterud, A., Langvatn, R., Lorenzini, R., Hmwe, S. S., Lehoczky, I., Hartl, G. B., Stenseth, N. C., Jakobsen, K. S. (2009) Phylogeography of red deer (Cervus elaphus) in Europe. J. Biogeogr. 36, 66-77.

29. Szabolcsi, Z., Egyed, B., Zenke, P., Pádár, Zs., Borsy, A., Stéger, V., Pásztor, E., Csányi, S., Buzás, Zs., Orosz, L. (2014) Constructing STR multiplexes for individual identification of Hungarian red deer. J. Forensic Sci. 59, 1090-1099.

30. Tamura, K., Dudley, J., Nei, M., Kumar, S. (2007) MEGA4: Molecular Evolutionary Genetics Analysis (MEGA) software version 4.0. Mol. Biol. Evol. 24, 1596-1599.

31. Tamura, K., Stecher, G., Peterson, D., Filipski, A., Kumar, S. (2013) MEGA6: Molecular Evolutionary Genetics Analysis version 6.0. Mol. Biol. Evol. 30, 2725-2729.

32. Wada, K., Nishibori, M., Yokohama, M. (2007) The complete nucleotide sequence of mitochondrial genome in Japanese Sika deer (Cervus nippon), and a phylogenetic analysis between Cervidae and Bovidae. Small Rum. Res. 69, 46-54.

33. Wada, K., Okumura, K., Nishibori, M., Kikkawa, Y., Yokohama, M. (2010) The complete mitochondrial genome of the domestic red deer (Cervus elaphus) of New Zealand and its phylogenic position within the family Cervidae. Anim. Sci. J. 81, 551-557.

34. Wang, Q., Yang, C. (2013) The phylogeny of the Cetartiodactyla based on complete mitochondrial genomes. Internat. J. Biol. 5, 30-36.

35. Yang, C., Li, P., Zhang, X., Guo, Y., Gao, Y., Xiong, Y., Wang, L., Qi, W., Yue, B. (2012) The complete mitochondrial genome of the Chinese Sika deer (Cervus nippon Temminck, 1838), and phylogenetic analysis among Cervidae, Moschidae and Bovidae. J. Nat. Hist. 46, 1747-1759.

36. Zachos, F. E., Hartl, G. B. (2011) Phylogeography, population genetics and conservation of the European red deer Cervus elaphus. Mammal Rev. 41, 138-150.

37. Zhang, W-Q., Zhang, M-H. (2012) Phylogeny and evolution of Cervidae based on complete mitochondrial genomes. Genet. Mol. Res. 11, 628-635.

38. Zsolnai, A., Lehoczky, I., Gyurmán, A., Nagy, J., Sugár, L., Anton, I., Horn, P., Magyary, I. (2009) Development of eight-plex microsatellite PCR for parentage control in deer. Archiv Tierzucht 52, 143-149. 